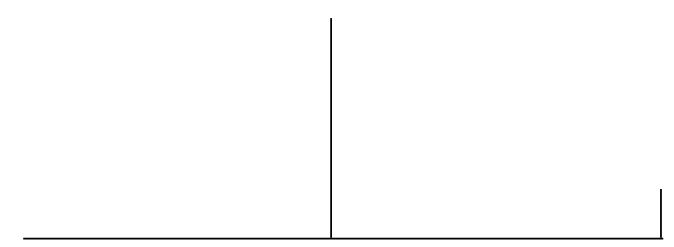

Rev. Latinoam. Psicopat. Fund., São Paulo, v. 13, n. 2, p. 361-367, junho 2010

Leite, Marcelo

Estresse, ansiedade, depressão

Folha de S. Paulo, 25 de abril de 2010, Mais!, p. 7

Couto, José G.

$\mathrm{O}$ rio e as margens

Folha de S. Paulo, 01 de maio de 2010, Esporte, p. 6

Magalhães Ana C. et al.

CRF receptor 1 regulates anxiety behavior via sensitization of 5-HT2 receptor signaling

Nature Neuroscience, v. 13, n. 5, p. 622-631, May 2010.

Gonzáles-Maeso, Javier Anxious interactions

Nature Neuroscience, v. 13, n. 5, p. 524-526, May 2010.

\title{
Estresse, ansiedade e depressão; não necessariamente nessa ordem
}

Guilherme Gutman

Em um desses finais de semana - quando, ainda que comprimido pela semana de trabalho que passou e por aquela que se aproximava, foi possível experimentar a breve e alentadora sensação de que a vida pode ser menos corrida ou 


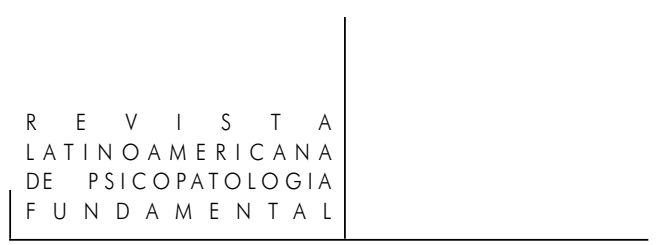

atarefada, abri preguiçosamente o Mais! - caderno dominical da Folha de S. Paulo - e, entre resenhas e artigos, me deparei com uma coluna que encurtou o meu domingo e que me antecipou a segunda-feira.

Não era para tanto; afinal, era só mais um texto no espírito "divulgação científica" - esse nicho do jornalismo no qual alguém mais ou menos "(de) dentro da ciência" procura fazer a útil e necessária ponte entre os leitores que não dominam o vocabulário em que são formuladas as, assim chamadas, descobertas científicas ${ }^{1}$ e as publicações acadêmicas que, objeto de um julgamento subjetivo que por si só já valeria um texto, eventualmente capazes de interessar a um público mais amplo.

É claro que quando o colunista precisa produzir semanalmente um novo texto - como parece ser o caso da coluna de Marcelo Leite - em alguns finais de semana se acertará mais e, em outros, menos. É que o desafio não é pequeno: primeiro, a "tradução" do jargão científico do artigo ou pesquisa originais em termos leigos; segundo, a demonstração convincente do suposto interesse prático do tema; e terceiro, fazer caber tudo isso, de forma sedutora ao leitor, no espaço de $1 / 4$ de folha de jornal!

Em sua coluna de 25/4/2010, intitulada "Estresse, ansiedade, depressão", a meu ver, o colunista é bem-sucedido no primeiro e no terceiro passos listados acima. Contudo, quando passa à demonstração do possível interesse que o tema que aborda poderia despertar (e que, provavelmente, despertou) incorre em pressupostos e simplificações que condicionam o argumento em uma direção que julgo imperfeita e que pode conduzir quem a acompanha a conclusões precipitadas.

De início, Leite (2010) convoca o leitor a notar a presença massiva, no mundo de hoje, dos tais formatos de sofrimento psíquico que dão título ao seu texto e que teriam como correlato o uso em larga escala de psicofármacos. Diz ele: "Anos atrás, causou espanto a revelação numa festa: em meio à dúzia de parentes e amigos, só uma não se medicava com ansiolíticos ou antidepressivos”, para, na sequência, diagnosticar: "É uma epidemia".

Tendo sugerido (logo se saberá quais as prováveis razões para tal sugestão) uma certa coesão entre os elementos dessa trindade sintomatológica pós-moderna - estresse, ansiedade e depressão - Leite procura articular um certo empirismo

1. Para que se reconheça a importância desses divulgadores da ciência (no melhor sentido da expressão), basta que se lembre de dois nomes: Stephen Jay Gould (1941-2002) e Oliver Sacks (1933 -); o primeiro, escrevendo primordialmente sobre a teoria da evolução, dinamitou crenças apoiadas na ciência, como o racismo científico. O segundo, pelo relato de casos neurológicos desconcertantes, chacoalhou as noções ortodoxas de doença e de normalidade. 
cotidiano ("Nas megacidades do presente, o que oprime são os atrasos no trânsito, insegurança profissional, violência imaginária e afetos embaralhados") às razões da ciência, que, sem provocar ruído, emergem no seu artigo com o status - jamais negado à ciência pela cultura na qual estamos inseridos, pelo menos desde o final do século XVIII - de um soberano como-as-coisas-são.

É nesta trilha argumentativa que, estabelecendo a ancestralidade evolutiva do estresse ("A evolução dotou os humanos com um sistema complicado para enfrentar perigos, reais ou de fantasia") e localizando o seu substrato fisicalista ["No centro (do tal 'sistema complicado') está o hormônio cortisol”], aponta o descaminho dessa virtude evolutiva: "O sistema legado pela evolução darwiniana se desregula e dá origem ao mal-estar da civilização: ansiedade. Nos casos mais graves (...) as fobias - ou ao abismo escuro da depressão". Ratificando a ideia de que há "uma ligação e uma gradação" entre os elementos da trindade, reconhece: "Não se conhecia bem (...) como se encaixam as peças do quebra-cabeça bioquímico que fornece o combustível do sofrimento" para, em seguida, esperançoso, afirmar que "com o trabalho de Ana Cristina Magalhães, agora se conhece um pouco mais".

\section{Notícias de um corpo}

O trabalho da cientista brasileira é de fato interessante; certamente mobilizou grandes esforços e muito tempo dos pesquisadores envolvidos, além de investimentos institucionais provavelmente altos. Lendo o artigo - naturalmente, redigido em linguagem e metodologia extremamente técnicas -, deparamo-nos com um exemplo de excelência do que se poderia chamar pesquisa básica orientada para fins humanamente úteis. Todavia, é precisamente nesta articulação entre determinadas descobertas relevantes sobre os mecanismos de funcionamento neural do organismo de um animal de laboratório e os possíveis usos clínicos de tais descobertas, que reside um outro - e dificílimo - desafio, em relação ao qual, fica a impressão, o colunista da Folha não reserva nenhuma linha para sua problematização epistemológica, andando rápido e entusiasmado demais em direção às imagináveis aplicações das recentes informações que coleta e apresenta.

No artigo original, os pesquisadores são parcimoniosos no estabelecimento de correlações entre os seus achados e sua utilidade nos domínios da clínica psiquiátrica. Eles notificam a relevância epidemiológica da comorbidade entre transtornos de ansiedade e transtornos depressivos e, também, que o estresse e a ansiedade são fatores de risco para o desenvolvimento de transtornos depressivos em geral. Fora isso, permanecem focados na demonstração de que 


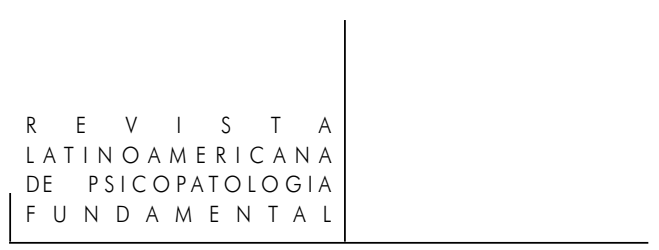

há uma articulação bioquímica entre o receptor para o fator liberador de corticotrofina (CRFR1) - mecanismo envolvido na produção de estresse - e o receptor para a serotonina $(5 \mathrm{HT}-2 \mathrm{R})$ - mecanismo envolvido na produção de sintomas depressivos.

É aqui, onde Magalhães et al. (2010) seguem contidos, que Leite é mais explícito: a pesquisa, embora não o diga claramente, é concebida e realizada tendo por pano de fundo a expectativa de que o esclarecimento de mecanismos neuroquímicos possa, de algum modo, iluminar a compreensão da natureza das experiências de sofrimento psíquico. Mesmo em declarações mais informais, presentes no texto da coluna, Magalhães é discreta, não chegando a sugerir que seu estudo diga o que é a depressão. No entanto, a pesquisadora (referida por Leite em sua coluna) aponta uma brecha aberta por seus achados para a intervenção farmacológica, na figura de um certo "composto químico capaz de bloquear a interação" entre os dois sistemas de receptores.

É preciso notar a enorme distância entre uma coisa e outra, isto é, o importante gap entre, para formular em termos bem simples, o que se passa no corpo quando alguém está estressado, ansioso ou deprimido e a natureza última daquilo que contemporaneamente reconhecemos como sintomas de ansiedade e/ou depressão.

Justiça seja feita, Leite não chega a postular que os referidos mecanismos bioquímicos, tornados mais claros pela pesquisa empreendida pela equipe de Magalhães - ou mesmo que qualquer outro esclarecimento, pretérito ou futuro, de como o nosso corpo funciona - determina as causas da depressão - sendo esta, de fato, um nome amplo sob o qual encontramos expressões clínicas bem distintas entre si. Ao contrário, Leite utiliza uma expressão feliz, exatamente porque não exige da descoberta em questão, mais do que ela poderia oferecer. Repete, ao se referir ao "quebra-cabeça bioquímico" que acompanha, a nível corporal, a experiência do estresse e da depressão, que se trata, apenas, de um "combustível do sofrimento". Numa analogia simples, é como se estivesse sendo postulado que o medo, por exemplo, não é causado por uma descarga adrenérgica disparada pelo corpo, mas que a experiência de medo, qualquer que seja a sua natureza, é feita tanto de acontecimentos físicos - taquicardia, palpitações, midríase, piloereção etc. - quanto dos eventos psíquicos que a caracterizam; é exatamente a combinação daquilo que o nosso cartesianismo insiste em separar em vivências corporais de um lado, e vivências psíquicas de outro, que é feita a familiar experiência de sentir medo. Ora, isso é completamente diferente de se afirmar que a causa do medo são certos acontecimentos neuroquímicos envolvendo neurotransmissores como a noradrenalina.

Se a pesquisadora brasileira, e mesmo Leite, são cuidadosos no estabelecimento de conexões entre a importância da pesquisa e seus hipotéticos desdobra- 
mentos clínicos, há autores que debruçados sobre a mesma questão fazem certas escolhas de vocabulário que tornam ainda mais transparente o modo como entendem o caráter de pesquisas como essa. Um exemplo pode ser encontrado no texto de Gonzáles-Maeso (2010), do Departamento de Psiquiatria e Neurologia da Mount Sinai School of Medicine - New York. Comentando o artigo de Magalhães et. al. (2010), ambos publicados - artigo e comentário - no mesmo número da Nature Neuroscience, reconhecemos os mesmos moldes da démarche de Leite (2010): numa perspectiva evolucionista, aponta não o "estresse", mas o "medo" como uma aquisição adaptativa da espécie que, sob certas condições, sofre o tal descaminho que deságua em ansiedade patológica e/ou estados depressivos. No entanto, Gonzáles-Maeso utiliza frases e palavras que não traem a sua crença tácita em uma psiquiatria cujas perguntas fundamentais deveriam ser formuladas à Ciência (com maiúscula mesmo). Lê-se, por exemplo, que

Infelizmente, ainda não temos uma compreensão clara de porque isso acontece (o desenvolvimento de reações fóbicas a situações ansiogênicas). A ausência de alterações patológicas claras no cérebro de indivíduos com transtornos psiquiátricos tais como ansiedade e depressão é, atualmente, um dos aspectos mais desafiadores da pesquisa nas neurociências. (Gonzáles-Maeso, 2010)

Algumas coisas chamam atenção no trecho acima transcrito: primeiro, a presença de um "ainda não temos", que revela a expectativa de que a Ciência, marchando de forma ascendente e retilínea, ainda não teria encontrado os métodos, ou ainda não teria tido o tempo necessário para, então, revelar a natureza última (ou penúltima) dos transtornos mentais; segundo, a expressão "alterações patológicas claras no cérebro", poderia, numa tradução livre, corresponder a algo como lamentavelmente ainda não encontramos as alterações, mas ao menos, sabemos onde procurar! (p. 524).

Em outro trecho, pode-se ler “(...) a serotonina, e particularmente o receptor 5-HT2A, são importantes na etiologia da ansiedade e na resposta às drogas ansiolíticas" (p. 525). Além de apostar alto em um neurotransmissor e um de seus receptores como núcleos fisicalistas para eventos predominantemente mentais, o autor dá um salto epistemológico gigantesco quando parte da constatação de que a serotonina está envolvida nos mecanismos neurais da ansiedade e aterrissa no estabelecimento de conexões e de ilações causais. Parece confundir, também, o mecanismo e o local de ação de psicofármacos - no caso, de ansiolíticos - com a possibilidade de, a partir da elucidação de um dos vários segmentos da ação de tais drogas, estipular localizações etiológicas. 


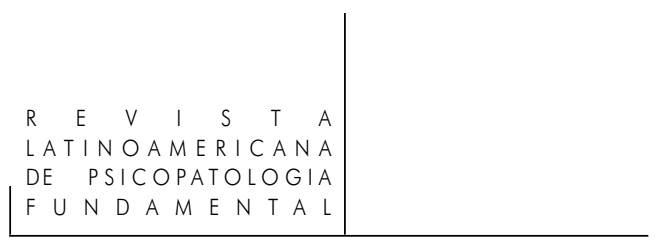

\section{"Coda"}

E para não dizer que, encastelados em uma torre de marfim, permanecemos alheios à chegada da Copa do Mundo de Futebol (deveríamos?), concluo este texto com um comentário sobre uma coluna publicada na seção de esportes da mesma Folha de S. Paulo.

José Geraldo Couto (2010) começa assim uma de suas crônicas esportivas:

Cada pessoa reage de modo diferente a situações de pressão. Disso resultam em grande parte a diversidade, o fascínio e também as dificuldades e perigos da convivência humana.

Tudo isso para falar de Diego Souza e sua reação desaforada e intempestiva às vaias que parte da torcida palmeirense dirigia a ele no Parque Antarctica. (p. 6)

E termina assim:

É aí que entra a psicologia, de certo modo a ciência que estuda os limites de cada indivíduo e o melhor modo de lidar com eles. Mas no mundo do futebol ainda há quem ache que a psicologia é frescura. (ibid.)

Não há dúvida de que Couto faz uma defesa simpática da importância da psicologia nos esportes. Além disso, não seria surpreendente que esta singela menção à relevância da psicologia tenha mais alcance e mais importância - em termos numéricos e de diversidade de alvos - do que um texto escrito para qualquer seção de um segmento, digamos, supostamente mais intelectualizado do jornal (como o caderno Mais!). Todavia, a utilização da psicologia para pensar a situação de um jogador que, pressionado por sua torcida reage de modo disruptivo, desenha, em Couto, linhas que não acrescentam muito à sabedoria popular de que, em alguém estressado um acontecimento a mais pode ser a gota d'água que fará transbordar o conteúdo do cálice. Bem, se há uma coisa que a psicologia ensina, é que um ato extremado não corresponde exatamente ao acúmulo e transbordamento de qualquer coisa - neste caso, numa imagem que sugeriria um modelo hidráulico do funcionamento psíquico. Como pudemos explorar um pouco em outro texto (Gutman, 2010), as razões para suportar, ou romper (às vezes, rompimento extremado) não podem ser explicadas por equações quantitativas, mas por complexidades que devem ser singularizadas e que, portanto, causalidades universalizantes não poderão alcançar.

Em tempo: logo antes de mandar este texto para a publicação, surge na edição de 16/5/2010 da Folha de S. Paulo, no próprio caderno Mais!, a notícia de que este deixará de circular. Decidi deixar o texto recém-concluído sem modificações, mas não posso deixar de mencionar que neste derradeiro Mais! está a última coluna de Leite (intitulada "Sete anos e nove meses", numa referência ao tempo em 
que ela foi sendo publicada). Nesta, há um balanço de beleza ética do que foi essa coluna ao longo de tanto tempo (cerca de 370 textos!): erros, acertos e, por fím, a promessa da bem-vinda teimosia de continuar essa empreitada algures.

Até a próxima edição!

\section{Referências}

Gould, S. J. A falsa medida do homem. São Paulo: Martins Fontes, 1991.

Gutman, G. "Nem tanto e nem tão pouco: a relação entre homicídio e psicose". Revista Latinoamericana de Psicopatologia Fundamental, São Paulo, v. 13, n. 1, p. 144-149, $\operatorname{mar} / 2010$.

SACKS, O. Um antropólogo em Marte: sete histórias paradoxais. São Paulo: Companhia das Letras, 1995.

Guilherme Gutman

Psiquiatra e psicanalista; doutor em saúde coletiva pelo Instituto de Medicina Social da Universidade do Estado do Rio de Janeiro - UERJ (Rio de Janeiro, RJ, Brasil); professor adjunto do Departamento de Psicologia da Pontifícia Universidade Católica do Rio de Janeiro - PUCRio (Rio de Janeiro, RJ, Brasil).

Rua Visconde de Pirajá, 595/905 - Ipanema.

22410-003 Rio de Janeiro, RJ, Brasil

Fone: (21) 9106-7009

e-mail: guilhermegutman@gmail.com 